石油技術協会誌＼cjkstart第 83 巻＼cjkstart第 1 号（平成 30 年 1 月） $27 ３ 3$ 頁 Journal of the Japanese Association for Petroleum Technology

Vol. 83, No. 1 (Jan., 2018) pp. 27〜33

\begin{tabular}{c}
\hline 論 $\quad$ 説 \\
Original Article
\end{tabular}

\title{
アナログデータを用いた石油の移動・集積リスク評価*
}

\author{
守 屋 俊 治 ${ }^{* *+}$
}

(Received September 4, 2017 ; accepted January 12, 2018)

\section{Improving petroleum migration risk analysis by using play analogues}

Shunji Moriya

\begin{abstract}
The greatest challenge in petroleum migration risk analysis arises from the fact that specifying migration pathways is extremely difficult by using currently available data such as 3D seismic, due to their insufficient resolution. Utilizing petroleum play analogues as indirect data is, therefore, one of the important approaches to improve the analysis.

An example from UK North Sea pre-Cretaceous plays was shown to demonstrate validity of the approach. Historical exploration well data drilled in the common petroleum system or plays were collected, and the relationship between migration-related parameters and drilling results was statistically analyzed. It revealed that migration style, reservoir age and migration distance are the parameters most strongly related to successful or failed migration. Those statistical analysis results can be used as reference to determine migration chance factor for the plays, which subsequently helps to determine that for undrilled prospects.

Petroleum migration risk analysis by using play analogues must be combined with other methods such as well/ seismic shows analysis and petroleum system modeling. Systematic and integrated approach must lead to better understanding and risking of plays/prospects, and new insight into further exploration potentials.
\end{abstract}

Keywords : petroleum migration risk analysis, play analogues, migration chance factor

\section{1. 緒言}

石油の移動・集積は，探鉱プロスペクトに対する地質リ スク評価において予測することが最も困難な要素の 1 つで ある。実際, 移動・集積が試掘井不成功の原因とされ，し かも，試掘前にリスクとして認識されていなかった例は多 い（佐藤ほか, 2004）。

移動・集積リスク評価が困難な理由は, 移動・集積が他 の石油システム要素 (根源岩, 貯留岩, シール, トラップ) と異なりプロセスであること（石油技術協会, 2013）に加 え, キッチンからトラップに至る移動経路全域について必 要な情報を必要な精度で得ることが不可能なことにある。 すなわち，移動・集積リスクを正しく評価するためには, 堆積盆全体の埋没史と熱史を復元してキッチンにおける生

* 平成 29 年 6 月 14 日, 平成 29 年度石油技術協会春季講演会, 地 質・探鉱部門シンポジウム「地質リスクと不確実性評価」にて講演 This paper was presented at the 2017 JAPT Geology and Exploration Symposium entitled "The Geological Risk Assessment and Resource Uncertainty on Technical Evaluation" held in Tokyo on June 14, 2017.

** 石油資源開発侏) Japan Petroleum Exploration Co., Ltd.

† Corresponding author : E-Mail : shunji.moriya@japex.co.jp
成・排出とトラップ形成のタイミングを決定し，そのとき の構造形態, キャリアベッドや断層の分布と性状を詳細に 把握した上で移動経路を特定し，移動の可否を論じる必要 がある。しかし, 多くの探鉱案件では, キッチンからトラッ プまでをカバーする十分なデータが得られていることは稀 なため, 質・量とも不十分な情報をもとに移動・集積リス ク評価を行うことを強いられる。

小論では, 移動・集積リスク評価の現状と課題を考察し た後, 改善に向けた取り組みのうち, アナログデータを用 いた評価の重要性について論じる。

\section{2. 移動・集積リスク評価の現状と課題}

\section{1 移動・集積リスク評価項目}

通常, 探鉱プロスペクトに対する移動・集積リスク評価 は, キッチンにおける生成・移動とトラップ形成のタイミ ング, キッチンからトラップへの移動経路という 2 つの項 目について行われる（Otis and Schneidermann, 1997 ; 佐藤 ほか, 2004)。小論では, 移動・集積に密接に関わる要素 としてこれらに「生成・排出量」を加え, また移動経路を「位 置関係」と「キャリア」に二分して, 以下の 4 項目につい 
て評価の現状と課題を考察する。なお，ここではキャリア をキャリアベッドや断層など, 石油の移動経路となる媒体 を指すこととする。

(1) キッチン・フェッチエリアでの石油の生成・排出量 (generation/expulsion)

（2）生成・移動とトラップ形成のタイミング (Timing relative to trap formation)

(3) キッチン・フェッチエリアとトラップの位置関係 (Position of trap with respect to kitchen/fetch area)

（4）キャリアの有無 (Connection of carriers to reservoir)

\section{2 移動・集積リスク評価の現状と課題}

従来から用いられてきた移動・集積リスク評価手法は, 一次元地化学モデリング (生成・排出シミュレーション) などで推定した生成・排出の夕イミングにおける復元構造 図や復元断面図を作成し，それを元に想定キッチンからト ラップへの移動経路を推定する，というものである。この とき, 側方移動経路としてのキャリアベッドや垂直移動経 路としての断層の分布や性状は, 必ずしも定量的に評価さ れないことが多い。

最近では, 三次元石油システムモデリング (生成・移動 シミュレーション）を用いた評価がますます多用されるよ うになってきている。実際, ダイナミックなプロセスであ る埋没史と熱史を再現する上で，三次元シミュレーション は有効な手法である。とくに, 根源岩からの生成・排出, トラップ形成のタイミング，想定キッチンエリアとトラッ プの三次元的な位置関係を評価するためには最適のツール といえるだろう。しかしながら，キャリアベッドや断層の 分布や性状に関しては，堆積盆全体にわたつて必要な精 度で情報を得ることは依然困難であり，その不確実性が 計算結果に与える影響は非常に大きい（守屋ほか，2007； Childs et al. 2009)。

そもそも，石油はキャリアベッドのごく限定された領域 を移動すると考えられており（Schowalter, 1979 ; Dembicki and Anderson, 1989)，また，しばしば垂直移動経路とされ る断層についても, 断層を介した併置関係や断層岩の不均 質性などミクロな性状が通路となるかシールとなるかに重 大な影響を与えると考えられている（Vrolijk et al. 2016）。 このようなミクロな地質状況までも把握可能な高分解能の デー夕取得技術が開発される可能性は, 将来的にも極めて 低い。

石油の移動経路となるキャリアベッドや断層などの分布 と性状, すなわち前節で示した 4 項目のうちの「キャリア」 を精度よく決定できない状況では，どのような手法を用い るにしても，信頼性の高い評価結果を得ることは容易では ない。移動・集積に関する本質的な課題は，移動経路とな るキャリアの可視化が不可能な点にあるといえよう。

\section{3. 移動・集積リスク評価の改善に向けた取り組み}

このような課題を抱える中, 三次元地震探査データや三 次元地質モデルの高精度化, あるいは効率的な不確実性評 価など，評価の改善へ向けた取り組みが継続されている。
とくに注目すべきは，キッチンエリアを含めた広域三次元 地震探査デー夕取得の普及により, 移動経路上に残される 小規模な集積を示唆するアノマリーや，トラップからの リークを示唆するガスチムニーなどが, 理想的な条件下で は検知されるようになってきていることである（例えば Loseth et al. 2009)。すでに述べたように, 個々の移動経路 自体を可視化することは不可能であるが，小規模なトラッ プに集積した石油や移動経路が密集している領域など，よ り規模の大きい現象を捉えることは可能になってきてい る。それらを丹念に抽出することで, 移動経路を部分的に 特定ないし推定することが可能になると考える。

一方で，そのような直接的デー夕による評価とは別に, 間接的デー夕（アナログデータ）に基づく評価精度向上を 目指すことも重要であろう。アナログデータに基づく評価 とは, 対象とするプロスペクトと同一のプレイの既存試掘 井について移動・集積に関連するパラメータと掘削結果に 関する情報を収集・分析してデータベース化し, その統計 データをプロスペクトの移動・集積リスク評価に利用しよ うというものである (Sluijk and Nederlof, 1984)。このよ うなアナログデータに基づく評価を, 直接的データによる 評価やシミュレーションなど他の手法と併用することによ り，移動・集積リスク評価の精度向上が期待できる。

次章では, アナログデータに基づく移動・集積リスク評 価の例として英領北海におけるアナログデータ分析例を紹 介し，その有用性を示したい。

\section{4. アナログデータを用いた移動・集積 リスク評価－英領北海の例}

\section{1 アナログデータ分析の目的}

アナログデータ分析の第 1 の目的は，2.1 節で挙げた 4 つの移動・集積リスク評価項目のうち，とくに「キャリア の有無」の評価に資することである。地震探査データなど による可視化が困難なこの項目の評価において，アナログ データが果たす役割は大きい。一方, 他の 3 項目は, 埋没 史・熱史の復元と地化学モデリングあるいは石油システム モデリングを適切に行うことで, 結果に対する不確実性は 残るものの, 評価は可能である。

第 2 の目的は, アナログデータ分析を通じた石油システ ム・プレイの理解である。統一的な基準でシステマティッ クに整備したアナログデータベースを用いることで, 評価 者個人の知識や経験に基づく属人的な評価を排し，より客 観的な評価を行うことも，このような分析の重要な目的で ある。

\section{2 収集データ}

主として公表文献・公表データ（Erratt et al. 2005 ; Mathieu, 2015 など）を用いて，1967～2013 年にかけて英 領北海でジュラ系あるいはそれより下位の貯留岩をター ゲットに掘削された試掘井 274 坑のデータを収集した（図 1)。これらは, 地理的にはViking Graben から Central Graben および Moray Firth に分布しており，約 $70 \%$ が根 源岩である Kimmeridge 頁岩層とほぼ同層準である上部 

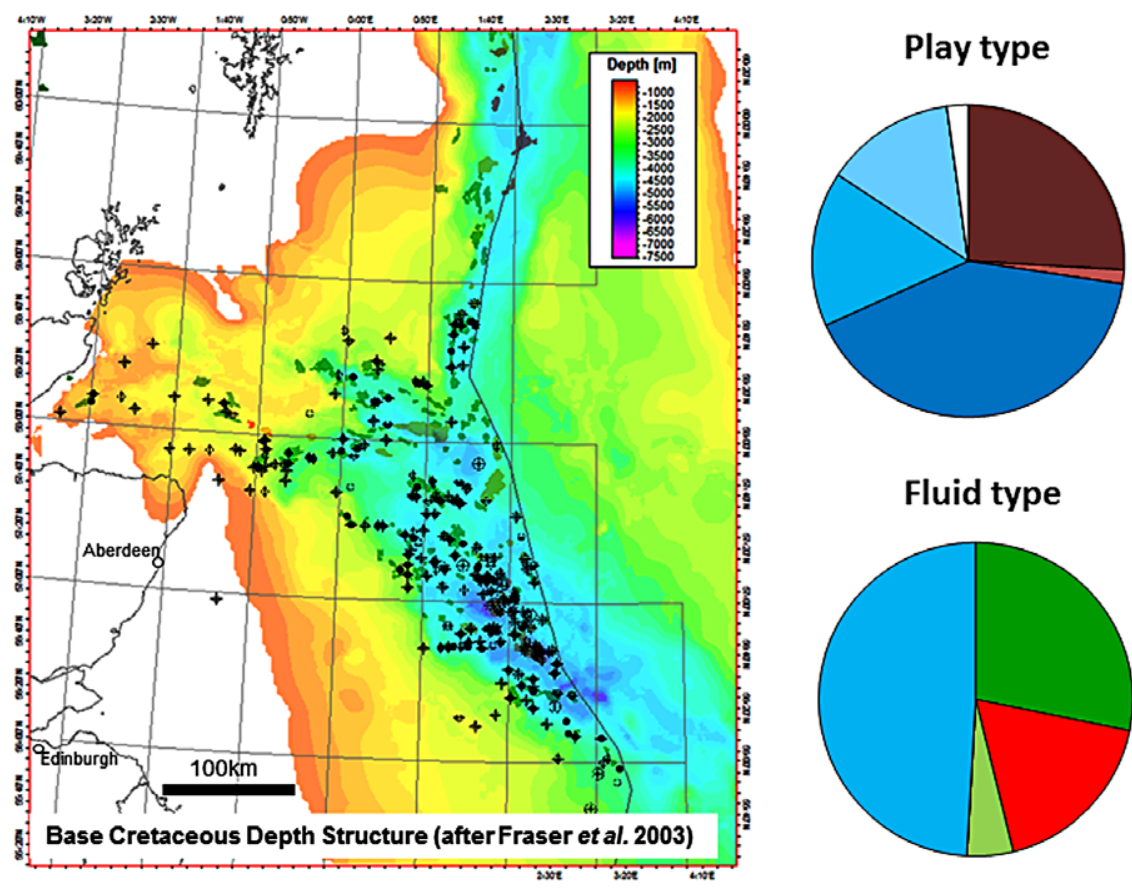

$\square$ Pre-rift structural

$\square$ Pre-rift combination

$\square$ Syn-rift structural

$\square$ Syn-rift combination

$\square$ Syn-rift stratigraphic

$\square$ N.A.

Fluid type

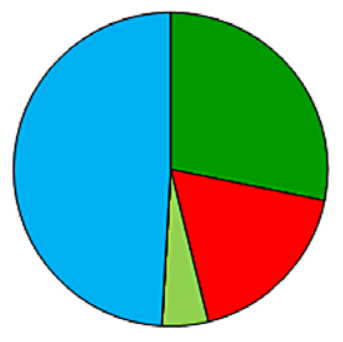

$\square$ Oil

$\square$ Gas condensate

$\square$ Shows

$\square$ Dry

図 1 英領北海アナログデータ分析地域と収集した坑井データ
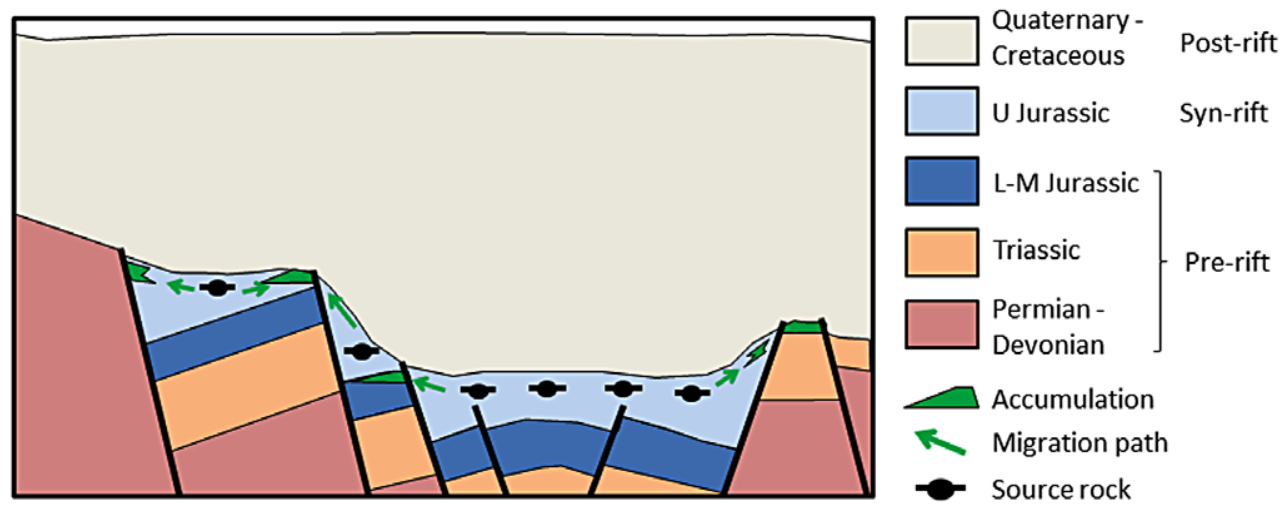

図 2 分析地域のプレイ概念図

ジュラ系のシンリフトプレイ, 約 $30 \%$ がそれより下位層 をターゲットとしたプレリフトプレイに対する試掘井であ る。トラップタイプとしては，67\%が構造トラップ， $14 \%$ が層位トラップ, 残りが組み合わせトラップとなっている。 図 2 に対象地域のプレイ概念図を示す。

収集にあたっては，デー夕が成功事例に偏ることを避け るため，なるべく多くの不成功井のデー夕を集めることを 心掛けた。ただ，結果的には成功井の割合が $46 \%$ と，当 該期間の実際の成功率（約 33\% ; UK Oil and Gas Authority のデータを元に算出した成功率）と比較して成功井に偏つ たデータセットとなっている。

収集データは坑井諸元, プレイタイプ, 掘削結果, 不成 功原因のほか, 生成・排出量, 移動様式, 垂直・側方移動 距離，断層を含めたキャリア・バリアの種類や性状，地層 圧力など，移動・集積に関わる各種パラメータである（表
1)。これらは掘削前に推定可能で, 統計的に扱うことで移 動・集積リスク推定に有効と判断したものである。

不成功原因は, 原則として出典資料の評価を踏襲し, 卜 ラップ, 貯留岩, シール, チャージ（根源岩＋移動·集積） の 4 つに分類した（図 3 (a))。しかし, 出典資料の評価が 不適当と考えた一部坑井については著者の解釈により修正 した。すなわち, 高圧高温 (HPHT) プレイでは不成功原 因をシールとしているものが多いが，その中には油・ガス 徵がない, 地層圧力が水圧破砕圧力を大きく下回っている など, 必ずしもシールが原因とは断定できないものがある。 このような坑井については「シールないしチャージ」ある いは「チャージ」に変更した。なお, 収集した 274 坑井の うち 12 坑（収集デー夕の $4 \%$ ）は不成功原因についての 情報が得られなかったため，不明とした。

ところで, 坑井掘削によって明らかになるのは, 厳密に 
表 1 英領北海アナログデータ分析に用いた収集データの事例

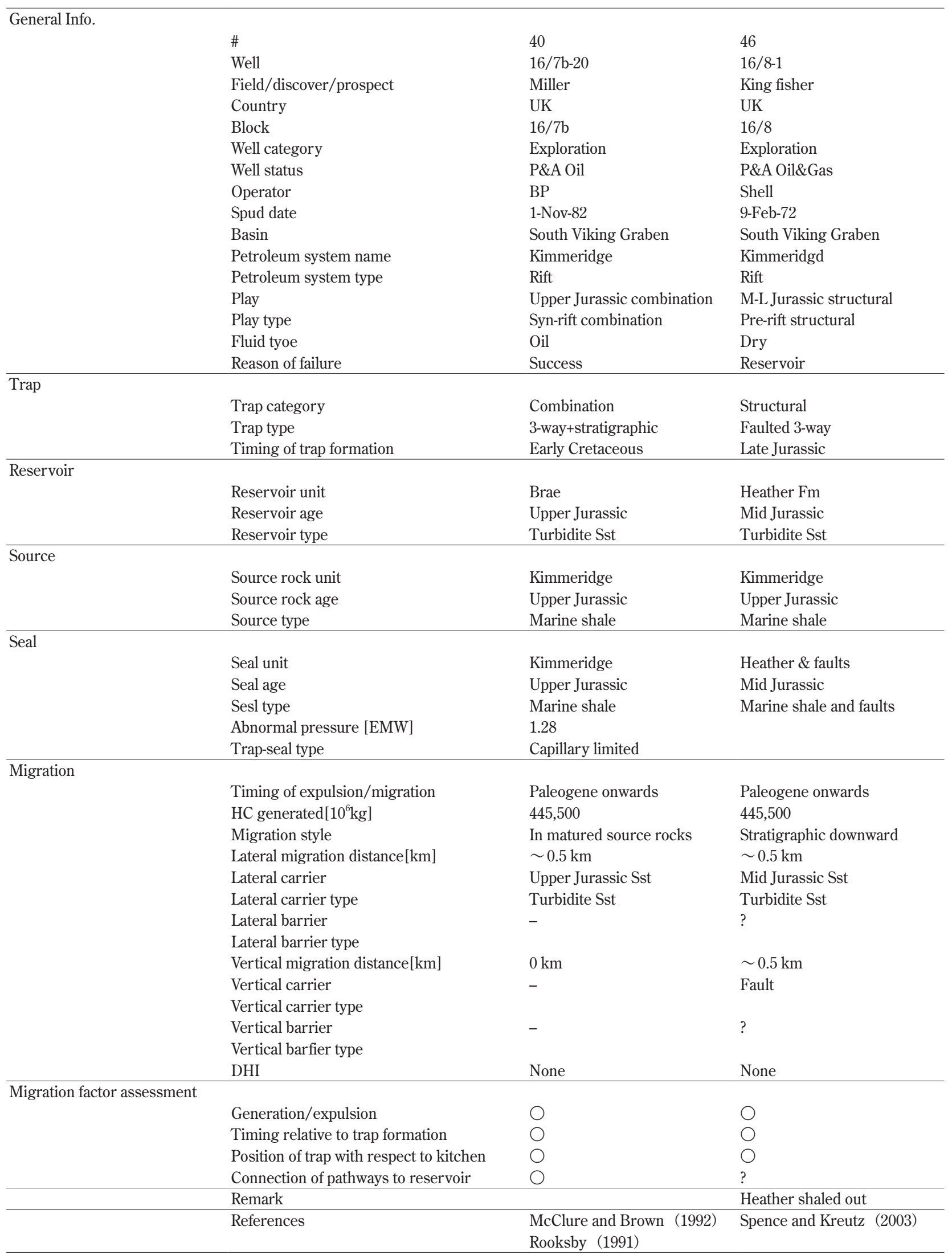




\section{(a) Reason of failure}

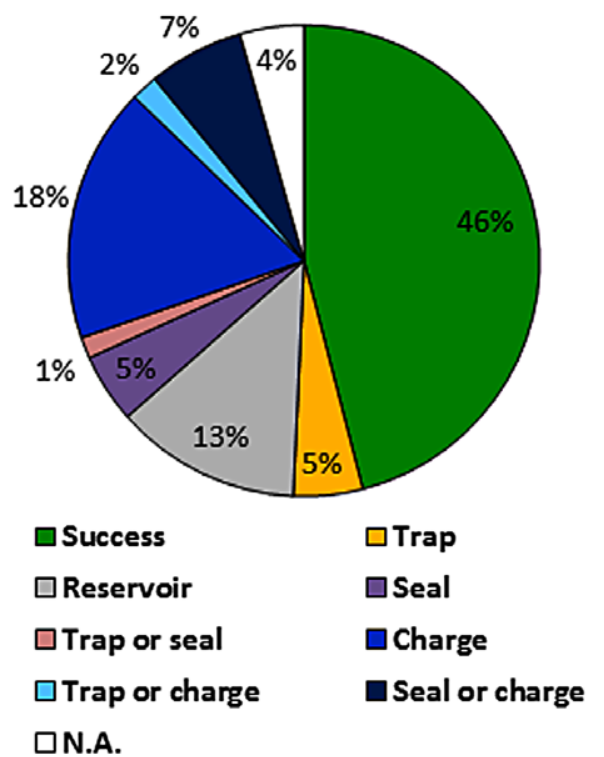

図 3 (a) 分析坑井の不成功原因。

\section{b) Migration factors assessment}

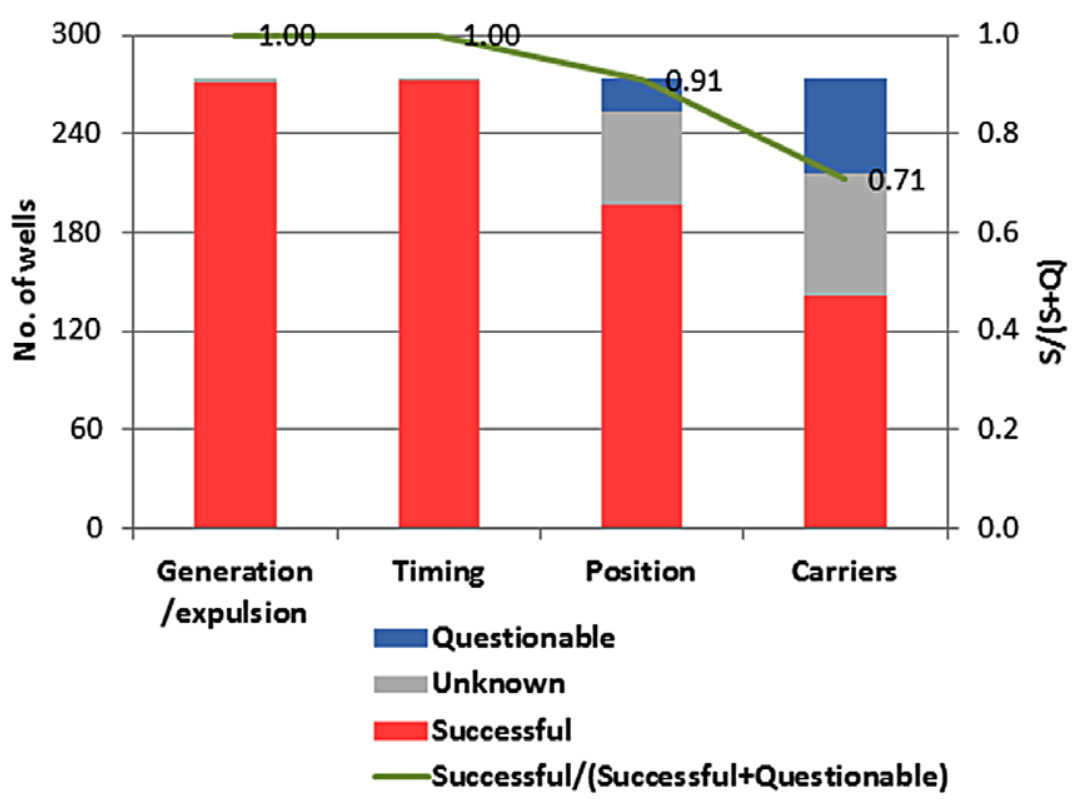

（b）移動・集積各要素の成否
は貯留岩の有無のみであり, その他の不成功原因や各種パ ラメータは, あくまでも著者を含めた評価者の解釈である。 したがって，以下に述べる分析結果には，解釈の任意性に 起因する不確実性があることには留意する必要がある。

\section{3 不成功原因分析}

不成功井 147 坑（収集データの 54\%）のうち, チャー ジが原因と推定されたものは 48 坑（同 18\%）であり，そ の可能性があるものを含めると 71 坑 $(26 \%)$ となる（図 3 (a))。これは推定された不成功原因として最多である。

チャージの成否原因をさらに分析するため, 成功井も含 めた全 247 坑について 2.1 節に示した「生成・排出量」「夕 イミング」「位置関係」「キャリアの有無」の 4 項目の成否 を集計した（図 $3(\mathrm{~b}))$ 。その結果, 生成・排出量と夕イミ ングに関しては, 問題ありと判断された坑井はなかった。 これは, 北海では上部ジュラ系 Kimmeridge 頁岩層が良好 な根源岩として広く分布していること, 坑井周辺の沈降部 では白亜紀から現在にかけて熟成に達すること（Kubala $e t$ al. 2003), それに対してトラップ形成時期は白亜系基底不 整合以前であることによる。

一方で, チャージに問題があった可能性がある 71 坑の うち, 58 坑においてキッチンからトラップまでの間のキャ リアの欠如が疑われた。これは, キッチンとトラップの位 置関係が移動に適している，すなわちトラップが有効な キッチンのフェッチエリア内にあるにもかかわらず，移動 の痕跡がないことから, 消去法として推定されたものであ る。おそらく, キャリアベッドの堆積学的な, あるいは断 層による連続性の欠如, 断層の垂直移動経路としての機能 の欠如などのケースがあると考えられる。

このように, 優秀な熟成根源岩が分布し, 一般には移動・
集積を含めたチャージのリスクが小さいと考えられている 北海においても, キャリア分布に対するリスクは少なから ず存在する。

\section{4 移動・集積評価}

収集した移動・集積に関わるパラメータと移動の成否の 関係を考察した。その結果, いくつかのパラメー夕は移動 の成否と関連することが明らかになった(図 4)。ここでは, そのうち 3 つについて考察する。

(a) 移動様式

図 4 (a) はプレリフトプレイとシンリフトプレイに分け て移動の成否を比較した図である。構造, 層位といつた卜 ラップ形態にかかわらず, プレリフトプレイでは移動の成 否率が約 $60 \%$ であのに対して，シンリフトプレイでは 成否率が $80 \%$ となっており，有意な差が認められた。前 者が層準的下方移動（Stratigraphic downward migration） が必要なのに対して, 後者は側方移動のみで集積可能であ ることが成否率の異なつた原因と考えられる。

(b) 貯留岩層準

図 4(b) は貯留岩層準ごとの移動の成否を比較した図で ある。上部ジュラ系はシンリフトプレイ, その他の中下部 ジュラ系, 三畳系, ペルム系, デボン系はプレリフトプレ イであるが, 注目すべきは三畳系の成否率が上部ジュラ系 と同様に高いことである。これは三畳系が砂岩優勢な岩相 が卓越しているため, 断層を介した層準的下方移動に有利 なことが原因と考えられる。

(c) 側方移動距離

移動距離と移動の成否にも明瞭な関連が見て取れる。と くに, 側方移動距離が $20 \mathrm{~km}$ を超えると移動の可能性が 著しく低下していることが分かる。これは, 側方移動距離 


\section{(a) Migration style}

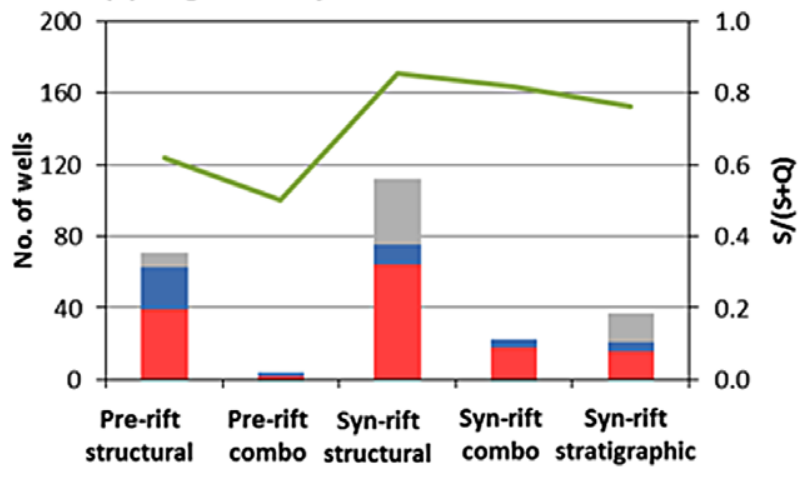

(b) Reservoir age

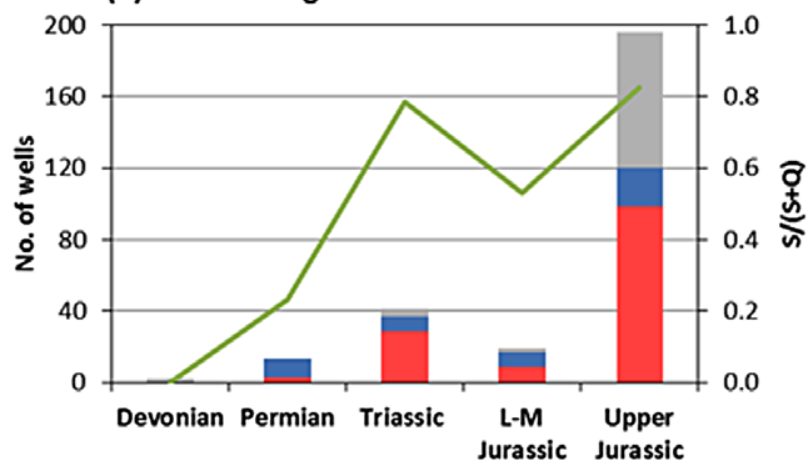

(c) Lateral migration distance

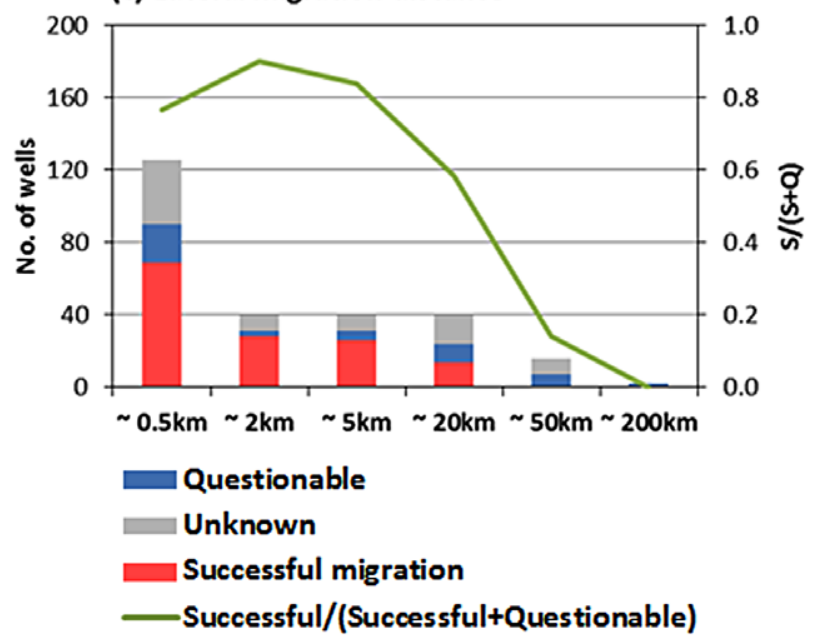

図 4 英領北海アナログデータ分析結果 移動様式 (a), 貯留岩層準(b), 側方移動距離 (c) と移動の成否

が長くなるにしたがって，キャリアがキッチンからトラッ プまで連続する可能性が低下することを示唆している。

4.5 アナログデータを用いた移動・集積リスク評価

前節の検討では, 移動梯式, 貯留岩層準, 移動距離と移 動の成否の相関が高いことが明らかになった。このような アナログデータは未試掘のプロスペクトの移動・集積リス クを評価する際の指標となると考えられる。すなわち，対 象とするプロスペクトと同一プレイに属する既存試掘井に ついて移動・集積に関連するパラメー夕と掘削結果に関す る情報を収集・分析してデータベース化し，その統計デー
夕を用いてまずプレイの移動・集積リスク評価值（チャン スファクター）を決定する。その上で，プロスペクト固有 の要素を加味して最終的な移動・集積チャンスファクター を決定することができる (White, 1993)。

アナログデータの移動・集積成否率の值をそのままプレ イのチャンスファクターとして用いるのが理想であるが, その可否は慎重に検討する必要があろう。まず，使用デー タベースが偏りのないものである必要がある。英領北海の 例では, 掘削された全試掘井に対する試掘成功率やプレイ タイプの比率は, 分析坑井のそれらとは異なっている。ま た，ここでは 1967 年から 2013 年までのデー夕を一括して 扱ったが，例えば 1960 年代と現在では利用可能なデー夕 やプレイに対する理解，あるいは残存ポテンシャルが異な ると考えられ，それを反映して成否率も変化している可能 性がある。しかし，今回の分析例のようにデー夕の偏りが 無視できない場合でも, 直接スコアに反映するのではなく, 相対的な評価として利用することは十分可能である。

\section{5. 結 論}

移動・集積リスク評価の本質的な課題は, 移動経路とな るキャリアの可視化が不可能な点にある。このような課題 を抱える中，三次元地震探査など直接的デー夕による評価 や石油システムモデリングなど, 評価の改善へ向けた取り 組みが継続されている。小論では, 改善に向けた取り組み のうち，間接的データ（アナログデータ）を用いた評価の 重要性について論じた。

アナログデータに基づく評価とは, 対象とするプロスペ クトと同一プレイの既存試掘井について移動・集積に関連 するパラメータと掘削結果に関する情報を収集・分析して データベース化し, その統計データをプロスペクトの移動・ 集積リスク評価，とくにキャリアの有無の評価に利用しよ うというものである。英領北海での検討では, 移動様式, 貯留岩層準, 移動距離と移動・集積の成否の相関が高いこ とが明らかになった。これらの統計データは, プレイのチャ ンスファクターを決定する際の指標として用いることが可 能である。その上で, プロスペクト固有の要素を加味して プロスペクトの最終的な移動・集積チャンスファクターを 決定することができる。

このようなアナログデー夕に基づく評価は, 単独で満足 できる結果をもたらすものではなく, 直接的デー夕による 評価や石油システムモデリングなど，すべてを組み合わせ て総合的に評価することが重要である。システマティック なワークフローを作成し，それにしたがって必要な評価項 目を網羅することで，より適切なリスク評価が可能となる と考える。そして，これらの作業を通じて石油システムや プレイについての理解が促進され，新たなプロスペクトの 創出につながっていくものと期待する。

謝 辞

石油資源開発株式会社には公表許可をいただいた。小論 は，2011 2015 年にかけて石油資源開発株式会社内で害 
施された技術開発課題「石油の移動・集積評価技術の高 度化」の成果の一部をまとめたものである。プロジェクト メンバーをはじめ，社内の諸氏からは多くの議論・助言を いただいた。また, 石油技術協会シンポジウム世話人の方々 には講演の機会を与えていただくとともに，執筆に際して ご協力を賜った。査読者には有益なご意見をいただいた。 以上の方々に心より感謝いたします。

\section{引用 文 献}

Childs, C., Sylta, Ø., Moriya, S., Morewood, N., Manzocchi, T., Walsh, J. J. and Hermansen, D., 2009 : Calibrating fault seal using a hydrocarbon migration model of the Oseberg Syd area, Viking Graben. Marine and Petroleum Geology, 26 (6), 764-774.

Dembicki, H. Jr. and Anderson, M. J., 1989 : Secondary migration of oil: experiments supporting efficient movement of separate, buoyant oil phase along limited conduits. AAPG Bulletin, 73 (8) , 1018-1021.

Erratt, D., Nicholson, P. H., Winefield, P., Milton-Worssell, R. J., Cayley, G. T. and Arter, G., 2005 : Exploration history of the high-pressure, high-temperature plays: UK Central North Sea. In Dore, A. G. and Vining, B. A. eds. : Petroleum Geology North-West Europe and Global Perspectives - Proceedings of the 6th Petroleum Geology Conference, 253-267, The Geological Society, London.

Fraser, S. I., Robinson, A. M., Johnson, H. D., Underhill, J. R., Kadolsky, D. G. A., Connell, R., Johannessen, P. and Ravnas, R., 2003 : Upper Jurassic. In Evans, D., Graham, C., Armour, A. and Bathurst, P., eds. : The Millennium Atlas: Petroleum Geology of the Central and Northern North Sea, 157-189, The Geological Society, London.

Kubala, M., Bastow, M., Thompson, S., Scotchman, I. and Oygard, K., 2003 : Geothermal regime, petroleum generation and migration. In Evans, D., Graham, C. Armour, A. and Bathurst, P., eds. : The Millennium Atlas: Petroleum Geology of the Central and Northern North Sea, 289-315, The Geological Society, London.

Loseth, H., Gading, M. and Wensaas, L., 2009 : Hydrocarbon leakage interpreted on seismic data. Marine and Petroleum Geology, 26 (7) , 1304-1319.
Mathieu, C., 2015 : Moray Firth - Central North Sea post well analysis. UK Oil \& Gas Authority, Aberdeen.

McClure, N. M. and Brown, A. A., 1992 : Miller Field: a subtle Upper Jurassic submarine fan trap in the South Viking Graben, United Kingdom sector, North Sea. In Halbouty, M. T. ed. : Giant Oil and Gas Fields of the Decade 1978-1988, AAPG Memoir, 54, 307-322, The American Association of Petroleum Geologists.

守屋俊治 - 山根照真 - 斎藤雄一 - 加藤 進 - 中山一夫, 2007 : 岩船沖油・ガス田のタービダイト砂岩への炭化水 素移動・集積モデル，石技誌，72(1)，89-97.

Otis, R. M. and Schneidermann, N., 1997 : A process for evaluating exploration prospects. AAPG Bulletin, 81 (7), 1087-1109.

Rooksby, S. K., 1991 : The Miller Field, Blocks 16/7B, 16/8B, UK North Sea. In Abbotts, I. L. ed. : United Kingdom Oil and Gas Fields, 25 Years Commemorative Volume, Geological Society Memoir, 14, 159-164, The Geological Society London.

佐藤大地・藤井康友・高山邦明, 2004 ：ポストオーディッ 卜導入によるプロジェクト評価精度向上，石技誌， 69 (6), 661-667.

石油技術協会, 2013: 石油鉱業便覧, 333-340, 石油技術協会.

Schowalter, T. T., 1979 : Mechanics of secondary hydrocarbon migration and entrapment. AAPG Bulletin, 63 (5) , 723-60.

Sluijk, D. and Nederlof, M. H., 1984 : Worldwide geological experience as a systematic basis for prospect appraisal. In Demaison, G. and Murris, R. J. eds. : Petroleum Geochemistry and Basin Evaluation. AAPG Memoir 35, 15-26, The American Association of Petroleum Geologists.

Spence, S. and Kreutz, H., 2003 : The Kingfisher Field, Block 16/8a, UK North Sea. In Gluyas, J. G. and Hichens, H. M. eds. : United Kingdom Oil and Gas Fields, Commemorative Millennium Volume. Geological Society Memoir, 20, 305314, The Geological Society London.

Vrolijk, P. J., Urai, J. L. and Kettermann, M., 2016 : Clay smear: review of mechanisms and applications. Journal of Structural Geology, 86, 95-152.

White, D. A., 1993 : Geologic risking guide for prospects and plays. AAPG Bulletin, 77 (12) , 2048-2064. 